\title{
The Empowerment of Village Law 06/2014 Implementation of the Village Law and the Sustainable Livilihood on The Improvement of Village Economy
}

\author{
Yuhelson, Muhamad Adystia Sunggara, Bambang Utoyo, Abdul Rahmat \\ \{yuhelson2870@gmail.com,muhamadadystiasunggara@gmail.com, bambangutoyo@gmail.com, \\ abdulrahmat@ung.ac.id\} \\ Jayabaya University Jakarta, Jakarta, Indonesia \\ Gorontalo State University, Gorontalo, Indonesia
}

\begin{abstract}
Poverty is the biggest challenge in every government regime. However, in reality, the Village Law, especially in Bantul Regency, is still a less meaningful development solution due to overlapping policies. Statistically, it hasn't addressed a better number or is still in place. In turn, the large allocation of funds disbursed by the government cannot automatically reduce this poverty rate. Occurring due to local government policies is still pseudo-not in accordance with the target. It was found that the Bappeda of Bantul Regency, in designing development programs using the method of community empowerment, still found government inconsistencies. Where the budget with program achievements does not match what you want to achieve. That is, the 2012 budget is still being used in 2013, and so on. In addition to the government's inconsistency in reducing poverty in Bantul Regency, poverty alleviation programs are still found to be pro-poor, not developing pro-jobs and pro-growth in increasing community participation. This will certainly have an impact on the development of sustainable development in the village as part of sustainable livelihood. At a point, the researchers recommend that the government immediately change its policy direction. With the hope of being one of the role models of sustainable development or the Village Law as a legal element in designing the program, it is one of the spirits in encouraging sustainable living in the village.
\end{abstract}

Keywords: Rural Development, Implementation of the Village Law, and the Sustainable Livilihood.

\section{Introduction}

By being modeled on the implementation of the Village Law No. 6, 2014 in each program development that boosts the economic improvement of the village[1-3]. The law on the Article 3 (three) points eight to 13 have very clearly been set full associated with independence, participation, equality, empowerment and sustainability. In addition, to promote sustainable development is then the government allocated funds large enough. The problem is the allocation of funds is so great, does not close the possibility will give birth to an anti-climax of the development itself. Although with large budget but not the main factor to resolve the problems of the village. But more than that the village must be effective enough space in developing themselves as independent villages as a turning point from the sustainable 
livelihood. This fact must be the point of press in development as the ideals of the reign of Jokowi-JK under the concept of nawa ideals [4] .

The concept of sustainable[5][6] livelihood is basically a turning point from the question of the village during is not interesting, deprecated and does not need to be discussed. Even though the source of the livelihood of all the inhabitants of the earth was born from the village[7]. Can imagine when villagers do not produce the source of livelihood of the people in the city (clothing-food-boards), what will happen? In this position we must be wise in respect of the question that appears. Thus the natural wealth[8][9] and the potential to be a source of strength of village-based economy to encourage the potential of nature that owned, for example use around the coastline[10] and the caves and the river rice fields under the land became the source of new livelihoods for the people of the village by presenting the economy eko-tourism (environmental services based economic activities). Thus, not excessive force in this case is one alternative to sustainable development in the village as role models [11].

To achieve sustainable village[12][13] is then in a broader perspective must be redefining the what is meant by poverty in the village, governence and poverty alleviation, alternative strategy the development of sustainable livelihood, advocacy and policy changes and real contributions from the institution of think thanks in maintaining villages as economic force of politics. From the five this perspective is auto-criticism for regional governments in developing village-based development[14]. Based on the question is supposed to each local government in the whole of Indonesia must think more focused and not only make the village as the object of the program is no exception for the government of Bantul District. The territorial in Bantul District is one of the potential areas in Yogyakarta Special Region (DIY). Wealth will be the potential of nature and the seriousness of the government in managing the local resources have a positive impact for sustainable village life [2]. One of concrete evidence stipulated in Government Regulation in Perda No. 16, 2010 about the management of the market. Where the bylaws will set very clear regulations retail market, the government emphasized the importance of efforts to do the revitalization of traditional markets to distribute the crops of villagers. Very poor in Bantul District franchises market as Indomaret employees, Alfamart, even mall, but more traditional market that developed in this area. In addition, before performing the revitalization of traditional market, in 2008, the government itself through the Decree of the Regent No 258, 2008 concerning the Establishment of a Management Unit Development Program Activities Participatory Development System (P2PP), has become the capital for the villagers to develop its citizens. Along with the program concurrent regulation of related center Village law No. 6, 2014, related technical guidelines of the Regent issued a legal product back through the Regent Decision No. 1, 2015, which technically monitor village budget and its implementation mechanism. So the decision issued by the government as a legal product is fresh air for the villagers to develop sustainable life. But with some amount of legal product issued by the government of how the impact on the community that is the object of the village program itself. This perhaps that we need to discuss more information, how the implementation of the village law for the people of Bantul. What is already running, when it is assumed, is of being alone or already take off vertically into the quality of the program in improving the economy villagers in general.

The village community empowerment program on the leadership of the Regent H. Idham Samawi should have been walking. Since then, community empowerment program the village called with Community Development alleviate poverty who walk in 2003. The budget for the program is quite prestigious, $70 \%$ of the budget funds. Usd 900 billion that huge stimulus plan in Bantul District Local Government is an effort to improve the welfare and community empowerment village (www.bantulkab.go.id/access14/12/2015). The question then, between 
local and central government programs that have direct access to this community empowerment, whether a significant effect or bore the dualism policy, for example, CMDMK program, PNPM Mandiri, to act on the village that the focus of his work involves active participation from the community.

Thus the changes in the way the views of the village community development with the spirit of the emergence of the Village Law No. 6, 2014, what is the impact on the community in a participative manner, independent, and harmonious. So the hope of restoring the village as a source of sustainable livelihoods have an impact on poverty reduction in the village. In addition, from some of the programs that have been running of course will see the extent to which the condition of the society of Bantul after.

\section{Theoretical Review}

Poverty is a complex social phenomenon, 'ill defined problem', is multidimensional [7]. In defining the poverty many of the tendency of an alternative distortion limited on physical appearance (body, food consumption, clothes, jewelry, house, household utensils, transportation used, lifestyle).In turn, distortion of the true meaning of impact measurement and indicators used by the government. The condition makes this land rigid in redefining poverty, so that has an impact on the number of poverty statistics, but the number that is served is not in accordance with reality in field.

Therefore, statistics that are presented by the BPS more tend to the question of the economy. Even though the other dimensions that supports the potential for people can be said to be poor or not, there is another indicator if necessary noted. But in general the measurement of poverty there are at least 4 (four) general classifications of poverty, namely (1) relative poverty, a direct result of the influence of the policy development that has not yet been able to reach all layers of the society. (2) absolute poverty, caused by the inability of society to fulfill basic needs to drink. (3) Poverty cultural, caused by factors indigenous peoples or the culture of a certain area is bound to make the poor. (4) structural poverty, helplessness against the system or the social order that is not fair and does not have access to free itself from poverty[1]. In addition, poverty has existed diverse, including low levels of income and productive resources that ensure sustainable life; famine and malnutrition and low levels of health; constraints and lack of access to education and other basic services; unrealistic conditions and deaths from the disease continues to increase; wandering life and living place that is not adequate; environment that is not secure and discrimination and social isolation. Poverty is also characterized by the low level of participation in the decision making process and in the life of civilians, social and culture[1-4]

This phenomenon is to urge the government to continue to strive for an improvement in the aspect of the poverty indicator. Through research conducted by the Center for Research and Development of the Ministry of Social Welfare (B2P3KS) Yogyakarta (2015), drawing up the concept and indicators of poverty. Where the design of this research achievements empties on 5 (five) primary indicator in measuring poverty, namely economic indicators, political, social, culture and psychological disorder. The experience of this research explored from various qualitative study to understand the perspective of society toward the poverty they experience. The consolidation of poverty studies involving the community (participatory), more emphasized on the study of studies that directly involves the poor. In this context, measure and compare the level of accuracy of quantitative counting with public perception [6] 
. Therefore, the commitment and the consistency of the government in improving economic growth (economic growth) in ways that just without exclude the poor will increase social integration with the politics that constituted by human rights, nondiscrimination, and giving protection to the less fortunate is the fact of social development paradigm [10]

\section{Reseach Method}

This research is a qualitative explorative research[5] The design of this research is presented in the form of the chimney (funnel). This form is a systematic steps that started from the exploration that is extensive and profound. Continue with the activities of the collection and analysis of the data that more narrowed and focused on a particular topic [13]. The nature of this research more inductive emphasized in narration that based on the critical perspective. [12]. This perspective is one of the part of rational scientific methods of empirical [15]. This research is based on the view of man as the instrument that have natural characteristics (naturalistic). It can be influenced by the definition of the model or the theory that is used. Because each researchers looked at the field of science that is being examined as the results of research in can tend to be interpreted based on the same phenomenon but with a different way[3].

To gather data sources a key from a research, then the technique of data collection this research include: (1) Secondary Data Collection. Secondary data associated with the dynamics of legislation Constitution No. 6, 2014, village chaperone, LSM, academics and other institutions. In addition the data based on the website will also become one of the reference in this review. The data can be in the form of legislation, data program achievements of the government, the report working program and activities and other important information related. (2)Interview In-depth Interview). In-depth interviews conducted against a number of the participants or speakers as follows: a) Bantul Regency government officials, b) Village chaperone, b) LSM activists are engaged on issues of community empowerment and c) Community Leaders and professionals. (3) the observation and study of the document. The data is also produced from the observation and study of the document. The observation is done through the visit to some of the villages assisted by, and other related institutions. Further Study of the documentation used to collect data was recorded both related to the results of the evaluation of the government related to the village, a report of the activities or programs and other documents[8] .

It uses various data sources, or in literature better known by the term triangulation, an effort to guarantee the authenticity and reliability of data in qualitative research. Triangulation itself simply can be described as a technique of checking the validity of the data to take advantage of the housing is something else outside of the data for the purpose of checking or as a comparison against the existing data. In this case, researchers apply trianggulation method with how to do cross-check against the results of the interview with the result of the study of the document. In addition, researchers also compare the results of the interview conducted with various stakeholders, government officials, tutor village, LSM activists, community leaders, and so on.

The analysis used in this research is Qualitative analysis, namely with how the data has been collated and arranged in a systematic, interpreted and analyzed so that can explain the understanding and the understanding of the symptoms are examined. The three components of the analysis of the data in the application form an interaction between the three with the data 
collection process as a cycle where the nature of the interaction of the three running continuously from the beginning of the process the researcher down into the field until the completion of the process of research.

\section{Discussion And Analysis}

\subsection{Villagers Sustainable Livelihood}

Village, as the imagination of life full of hope and ideals. This condition will be far from the dynamics of the development of massive urbanization process is done by the community. As a report that is presented by the PBB predicted, villagers will migrate to the city with the projection 66 percent on the year 2050 [9]. This statistical data such as zero sum game: develop the growth of the city are increasingly convince the population in the village will be left. This condition is a little concern, even the views guess, whether when there is no longer any villagers. The forecast loss of villagers, little not too much because there is no longer the source of livelihood for its citizens. Even though the source of livelihood of the people are the center of village. Layout of the basic human needs, when we want to be honest, is located in the village. Even if the first villages as a temporary movement, like the side of the currency which cannot be separated. Ahead of the Idul Fitri day arrived, the inhabitants of the city to prepare for going home to the homeland. Limited appointments miss speech friends of the past and place of birth nostalgia.

This phenomenon is plural found in almost all the areas of Indonesia. In the sociological studies, this is the fact that the village is still be the attraction for those who spent time in the city. In addition, in temporary movement of villagers to the city as part of the diversification strategy and ekstensifikasi labor utilization. As part of the strategy of the utilization of labor, unfortunately, development that oriented to the market mechanism, demanding villages is not interesting, stale question, and ingredients long story. On this condition is increasingly emphasized that the village will be more left and only become the ingredients of exploitation for them that have a great interest in the utilization of natural resources, potential, and the asset is owned by the village. The development is oriented to the market mechanism will have an impact on the income of the villagers and the social gap so high. The story of personal experience interest when an interview with researchers, he comes from Indramayu, went to Yogyakarta in 2004 not without reason. Interest is one that already has a congenital anomalies in himself. Many ridicule himself, decided to leave his hometown. But before he left the homeland, when prompted, interest is a trader which is quite successful in the traditional market. Sell the harvest from their own vineyard, it eliminates the market, with the spirit of business orientation and high enough. But because there is no accompanying himself, so he decided to leave his hometown. Stories told flowers, when he chose the way of life as a transsexual that every day everyday you can find red light Maguwoharjo, is not comparable with the first condition. Interest rates, living in Yogyakarta with only kos size $3 \times 3$ small room, and rely on the income from the become street musician. At this point, indicates that the potential of human resources, which has been established of life in the village, failed to be used.

Other stories experienced by the Trasno, a scavengers from Palembang. Trasno, when prompted, the condition of his life is very difficult to develop himself to live in the village, because there is no ability and skill of the individual. At a time, Trasno decided to migrate to 
big cities such as Medan, Jakarta, Bandung, until the last place in Yogyakarta[16]. Instead to develop a better life, thus lived in the town made himself more languish. Two stories above, indicates that live in the village of sustainable development cannot be used as a potential to restore life in the village. For the analysis in the story, and researchers analyze related hard thinking Chambers and Conways (1992) which refers to a better livelihood consists of ability, assets and activities required to become a better life. Conceptually, the development of hard thinking Chambers and the Conways manisfested into three main series, namely assets (man, psychological, nature and social), access (institutional, government, and economic source of political), and outcome. This is illustrated as the following asset based reduction flow:

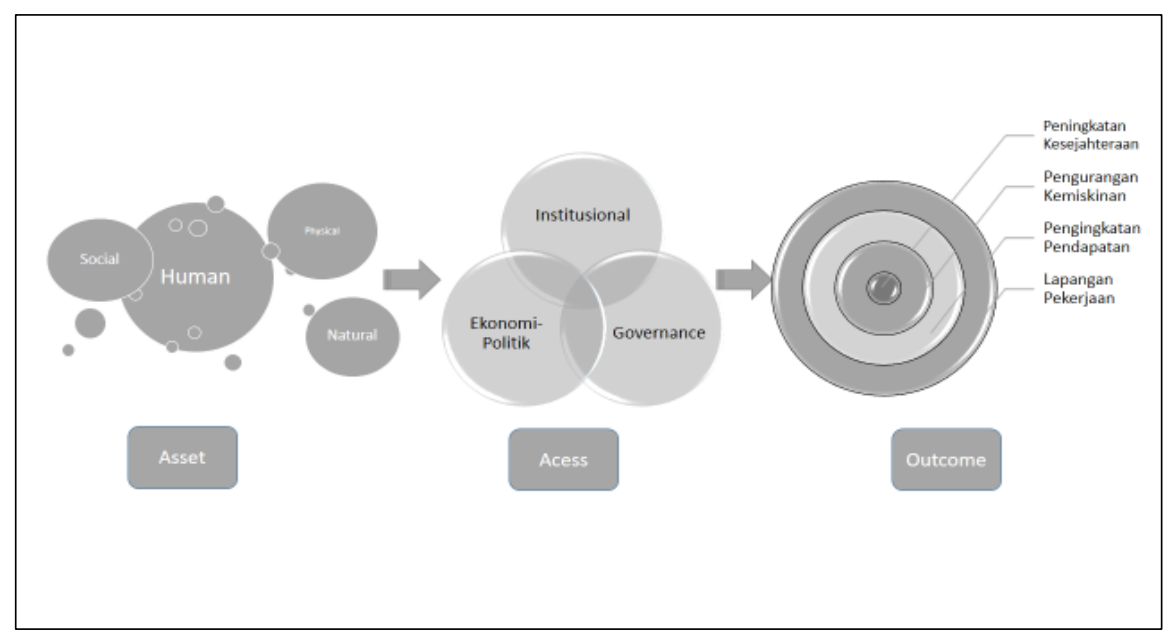

Fig. 1. Asset-Based Poverty Alleviation Flow

Source: Research of IRE, 2012

The Picture above shows that the potential source which is owned by the villagers there are at least three things that need to be noted, including: First, assets owned by men in developing itself into a better there are at least three attached to himself. (1) psychological problems is a condition of the individual psyche, whether he has encouragement psychologically or not to become a man. (2) Natural, instinctively human beings have the potential for each to develop themselves into better. (3) social factors, where and when the individual has a high social power will be very easy to adapt their good, so that encourage better livelihoods (gathered and organise). In view of the chambers and Conways (1992), the problem for the individual assets is divided into two things, namely the tangible assets and intangible assets. Tangible assets is the source of power relatively directed in control of the household or a person who is required to support and sustain the livelihood, as natural capital, financial capital, and phsical capital. While the assets of the intangible is the claim and access needed by the household to be able to take advantage of the resources or services that is relatively not in the control directly, such as human capital, social capital or political capital.

Second, human access that is facilitated by the state is institutional. In this way the government as the regulator can provide easy for individuals to develop themselves in their own good, a case of regulator, program/activities and allocation of funds budgeted figures. When this can be filled by the state organizer little many will enhance social solidarity and income gradually. The context of access owned by the man is basically the procurement of the ability to realize the self-individually. This can be realized through social relations, 
institutional and organization. Social relations can be ethnic tribes, religion, age, who can build unity in the community. So on the contrary, customs (institutional) plays an important role in the decisions that will be played by a man.

Third, the outcome as the end objective of poverty alleviation process itself When assets and access to the basis can be run by individuals and in turn will increase the welfare, poverty reduction capacity building, can even become a jobs. This can be realized in the development of the capacity of the individual who has developed orientation developing themselves and the community in which they live. To make changes to the community became an important point in the orientation that can create jobs. At this point the ownership of the asset will be able to be the individual capacity development capital is sustainable livelihoods strategy for man. This means that the understanding potential themselves, build orientation of the development of the capacity of the existence of an agreement between across ethnic groups in which the customs (institutional), with itself will build life which impact on social stability and a strong social relations. With the development of the portfolio can signal will develop increased revenue, welfare (out of poverty), resistance against vulnerability or economic pressure, even the survival of the economic opportunity that can be the next generation (sustainability).

\subsection{The Advocacy of Poverty Alleviation Policy Changes}

Poverty problem is the phenomenon of the world that is still only roar in every spheres of life. Responding to the problem by launches the countries in the world in the year $2000 \mathrm{~s}$ invites all countries to combat poverty, no exception for Indonesia. Documents globally, in turn sets the limit settlement of the poverty on 2015, with issues that are enshrined in the Millennium Development Goals (MDGs). How with Indonesia? Under the administration of President Susilo Bambang Yudhoyono, since 2004 until 2014, with confidence sets can reduce poverty 8-10 percent. Poverty data is escaped to achieved. The latest data shows that the national poverty rate still of 11,47 percent (BPS, 2014). Now, Jokowi-JK government also sets down the number of poverty 6-8 percent at the end of the term of office in 2019 (Bappenas, 2015). Whether the target of Jokowi will be done? This means that there will be the target of poverty reduction 3-5 percent. A number that is not ambitious but not as simple as seize it.

In the context of the reduction of the number of poor people public mafhum that money flowing rains for programs that have been designed. Then state funds pumped by tightly to immediately realize the poverty alleviation programs in the whole of Indonesia. This phenomenon also occurs in the area, Bantul Regency was no exception in DIY. Even though this area was made projects of the State Budget and the budget but the trend of poverty in Bantul District achievements statistic still shows positive numbers. Although Bantul District is not the poorest in DIY, but still the question of poverty in this area still be on the agenda that need to be addressed continuously. The severity of this can be seen that the poverty rate in Bantul District 16,97 percent, is located in the third position compared with the Sleman District 10,44 percent and the City of Yogyakarta 9.38 percent (BPS DIY, 2012). With the figure from year to year shows positive trend, because in 2011 ranging 17,28 percent. This means that every year decline 1.2 percent. Decrease the percentage of poverty is proclaimed no positive change in poverty alleviation. Even globally note released by the World Bank Indonesia to meet positive achievement in lowering the poverty rate. The growth rate of Indonesia 0.8 percent counted the fastest compared to a number of Asian countries such as China, Cambodia, and Thailand (0.1). However, lowering the poverty rate is still leaves the 
question gap between provinces in Indonesia. Not the spreading poverty reduction was caused directly by the between provinces. This Disparitas also narrowly defined economic growth gap between the regions, not escape also inter District.

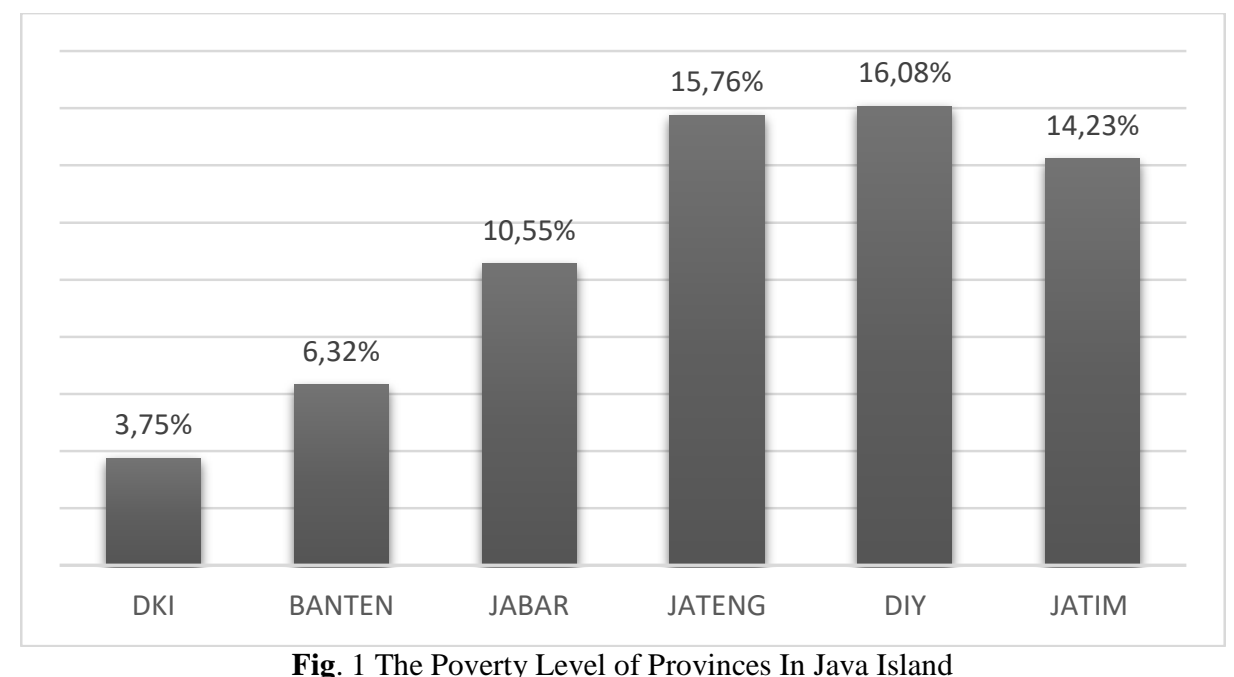

Fig. 1 The Poverty Level of Provinces In Java Island

The Picture above shows that the DIY have poverty most high among other provinces in Java Island (16,08\%). This should make us all warning early warning). Why? Because DIY is one of the areas in Indonesia that have the potential to live classified as a comfortable, safe havens. However turns out of the poverty rate in this area is high enough. In addition, based on the results of research done by Local Social DIY (2014), the city with the slogan adem, ayem, lan tentrem is predicted in the year 2021 will become the city of the purpose of the elderly population aging). When this happens then will become a burden and risk for citizens DIY, because Dependency rebuilder ratio will be higher again. The basic reason the elderly harbored to this Gudeg city because the cost of living cheap and natural conditions which has its own comfort other problem which became the phenomenon of poverty in DIY is the luster of wandering and beggars, street children, street singers and so on the families of marginal city.

Among the question of poverty, of course we asked why it can happen in DIY? Even though the budget to alleviate poverty good funds from the National Budget and the budget is high enough, but has not yet been able to conquer poverty society. In this case there is stigma changes between the business and the results. Factual news in field of course will be different from the story is the story presented by the community. The experience that is done by Komar a farmers in one of sub-districts in Bantul district. The story of a farmer business year 19641972 Komar is a priceless experience for us. Where He is able to consider the stigma that during the hopes this by local people in his neighborhood. Komar have paddy fields almost 2 hectares, during the period of time long enough for almost 30 years more, he and his family dependence on inorganic fertilizer as a direct impact of government policy program of the New Order regime, known as the green revolution.

At first the father of Komar every time the harvest when has 3 hectares of paddy fields can produce rice until reaching 10-15 tonnes. This means that in one hectare family Komar 3- 
4 tons. But after the imposition of the green revolution as the pusher self sufficiency in food, old then the fertilizer plant artificial fertilizer given free by the government, making Komar and family dependence on the fertilizer. Initially, the program has a positive impact in one hectare of rice paddy farmers can produce 2-3 tons. But after years of walking, turned out to be more fertile land and damaged by the inorganic fertilizer, causing shrinking production when harvest. Komar view this condition after many years he did initiate with change the course of farming, namely with back to the process of the use of organic fertilizer. This condition, 2005, he begin. The first years are difficult to convince the family and farmers around the place where he lived. It takes 4 years to prove that the way crops using organic fertilizer will succeed. The updated time progressed, now he is able to harvest the rice in one hectare between 2-3 tons. Of course, this success is not removed from the government program to encourage the imposition of the movement go organic for the farmers.

Another story that was done by Sutrisno, still in the Bambanglipuro. The assistance given by the government of Bantul District in 2005, with Community Development program alleviate poverty (CDMK), has succeeded in increasing the production of cattle for the group. Where it implements an integrated investment system. The harvest rice and green of yellowish green, he and his team take advantage of the green of yellowish green crops in paddy fields to give, livestock so that the cow dirawatnya can increase the production of cattle in this area. In other cases experienced by Marsina, a traditional market traders in Bantul Market. During the Bylaws Traditional Market management by the Regent H. Idham Samawi 2008, in addition to protect from the side of the regulation, other impacts can improve the productivity of the society in the sell their natural earth results in the traditional market. In the traditional market, Marsina only in a day Rp 1.000,00, as levies and the cleanliness of the market. But for himself as a merchant can produce net profit in a day between this 400.000,00100.000,00 until the small money, as long as the sources of income that he may have protected by the government.

From some of the story of the villagers, then we will find a variety of knowledge. They can be an important source of knowledge in order to formulate policies that carry their interests also. Three stories the story of villagers in the above can be an inspiration to the policy changes during this is thought by policy makers. The story of villagers in a turning point on the question of poverty and hunger and no shortage of nutrition, social conflicts due to the lack of jobs and so forth, carry now able to answer the question itself. This is a valuable lesson for policy holders related how to implement programs that target. In addition, this context asserts the evidence of the relevance of the ACT ON THE Village No. 6 Year 2014 [17] against the carefulness of society in the use of resources as the key source of provision and sustainable livelihoods. So we believe that poverty is not about statistics that during this became the main indicator measuring the level of success in development. The exploitation of natural resources are not renewable energy (non-renewable resources), is not the only the dynamics of poverty alleviation. Multi-dimensional realities of poverty is not just a mathematical figure that every year issued by the BPS. More than that, should the local government with some amount of your policy and program that will be designed to be elites to the potential local resources that belong to the community.

For at this point poverty alleviation programs in Bantul District, no exception with the ACT ON THE Village, must immediately realize the program appropriate for the villagers. Because ) data on field presence of inconsistency bureaucrats in designing empowerment program with the budget that has been agreed. For example, in work program on 2009 SKPD elites to empower villagers. But in the year 2010, the programs be number four so that at this point the lack of inskonsistensi from the government. Tackling poverty more emphasizes on the results of the program achievements/activities not on the process so that the program is 
even more emphasized on pro-poor mechanism. The dynamics of this thought must be changed. The spirit of renewable energy Village law, must be a door in the open the veil, that the design of the program should be more emphasized on pro-job and pro-growth to improve economic productivity side village community. Large allocation will be very useful for the development of sustainable village livelihoods. Thus the poverty alleviation is done by local government is still bumpy and inconsistency.

\section{Conclusion}

The Village law No. 6, 2014 is a new spirit for the government in implementing development with participatory community empowerment method. This method for some people to become the appliance is effective in implementing sustainable development in meet the target MDGs. That poverty is the biggest challenge in each government regime. But on the fact that the act of the Village, especially in Bantul District still become less important development solution due to the overlapping policy. These conditions have an impact on the improvement of prosperity and poverty reduction in Bantul District, statistically, not directed numbers are better or still stagnant. In turn, the allocation of funds huge stimulus plan by the government does not automatically can reduce poverty. Why can happen? The results of the analysis in field shows that this condition occurs as a result of the regional government policy still is not in accordance with the shadow being targeted. Found that the Bappeda Kabupaten Bantul, in designing development programs with community empowerment method is still found the extent of the inconsistency of the government. Where the budget with the program achievements is not in accordance with what you want to achieve. This means that the budget 2012 still payment is being allocated in 2013 , so on, so.

In addition to the inconsistency of the government in reducing poverty in Bantul District, still also found poverty alleviation programs are still pro-poor, not develop pro-job and progrowth in the participation of society. This of course will impact on the development of sustainable development in the village as part of the sustainable livelihood. At the point, then the researchers recommend to the government to immediately alter the course of its policies. With the hope to become one of the role models of sustainable development or Village law as a legal ground elements in designing the program, became one of the spirit in encouraging sustainable life in the village.

Semua tabel yang disertakan harus dirujuk dalam teks utama dan judul tabel harus diposisikan di atas tabel. Judul dan teks dalam table dituliskan dalam Times New Roman, 9pt.

\section{References}

[1] Abdul Rahmat, Ahmad Izudin. 2018. Impact Evaluation of Community Empowerment Programs with the Farmer Managed Extension Model. European Research Studies Journal Volume XXI, Issue 1, 2018. pp. 27 - 37

[2] Ahmad Izudin, "Kebijakan Pemerintah Tentang Pasar Tradisional di Bantul (Analisis Pemberdayaan Masyarakat)", Skripsi tidak diterbitkan, (Yogyakarta: Fakultas Dakwah dan Komunikasi UIN Sunan Kalijaga, 2012). 
[3] Deddy Mulyana, Metodologi Penelitian Kualitatif Paradigma Ilmu Komunikasi dan Ilmu Sosial Lainnya, (Bandung: Remaja Rosdakarya, 2003).

[4] Jim Gilling, Stephen Jones, dan Alex Duncan, "Sector Approaches, Sustainable Livelihoods and Rural Poverty Reduction", dalam Development Policy Review, Vol. 19, No. 3, Tahun 2001.

[5] Lexy J. Moleong, Metodologi Penelitian Kualitatif, (Bandung: PT. Remaja Rosdakarya, 2010), hlm. 27.

[6] Miles and Huberman, Qualitative Data Analisys, (Thousand Oaks: Sage Publication: 1994).

[7] Muhadjir Darwin, Memanusian Rakyat: Penanggulangan Kemiskinan Sebagai Arus Utama Pembangunan, (Yogyakarta: Media Wacana, 2005)

[8] Pramono, Nindyo, 2017, Tanggung Jawab Dan Kewajiban Pengurus PT ( Bank Menurut UU Nomor 40 Tahun 2007 Tentang Perseroan Terbatas, Buletin Hukum dan Kebanksentralan, Volume 5 nomr 3 Tahun 2017

[9] Robert Chambers dan G. Conways, Sustainable Rural Livelihoods: Practical Concepts for the 21st Century, (Bringhton, England: Institute of Development Studies, 1992).

[10] Saliman, Abdul R. dkk, 2005, Hukum Bisnis Untuk Perusahaan; Teori Dan Contoh Kasus, ed.kedua, cet.keempat, Jurnal Renada Media Group Jakarta, 18 (04), 332

[11] Sri Rahayu Wilujeng. (2017). Filsafat, Etika Dan Ilmu: Upaya Memahami Hakikat Ilmu Dalam Konteks Keindonesiaan. Jurnal HUMANIKA, 17(2), 235.

[12] Sugiyono, Metode Penelitian Kombinasi (Mix Methods), (Bandung: Alfabeta, 2013).

[13] Suharsimi Arikunto, Prosedur Penelitian Suatu Pendekatan Praktek, (Jakarta: Rineka Cipta, 1998).

[14] Sujani Zamroni (dkk), Desa Mengembangkan Desa Berkelanjutan, (Yogyakarta: IRE, 2015).

[15] Teresa Morris, Social Work Research Methods Four Alternative Paradigms, (USA: California University Press, 2006).

[16] Tim Peneliti, Desain Program Pelayanan Kesejahteraan Sosial Bagi Lanjut Usia Daerah Istimewa Yogyakarta, (Yogyakarta: Dinas Sosial, 2014).

[17] Undang-Undang Desa Nomor 6 Tahun 2014 Pasal 3 ayat 8-13. 